\title{
Bivalves from the white chalk (Maastrichtian) of Denmark, II: Arcoida
}

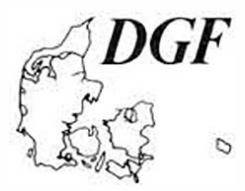

\begin{abstract}
Heinberg, C.: Bivalves from the white chatk (Maastrichtian) of Denmark. II: Arcoida. Bull. geol. Soc. Dersmark, vol. 27. pp. 105-116, Copenhagen, March 23rd, 1979.

https://doi.org/1(1).3757()/bgsd-1978-27-11

Eight new species of Arcoida (Bivalvia) are described. the genus belonging to the families Limopsidac, Arcidac. Noetidac and Parallelodontidac. Two species (Barbatia) are redescribed and revised. Pseudo-grammatodom Arkell, 1930, is rcinstated.
\end{abstract}

Claus: Heinberg. Instimu for historisk Geologi og Palazontologi, Oster Voldgade 10, DK-13.50 Kobet ihavn K. Denmark. July 4h. 1978.

The present paper is the continuation of a preceeding one on Limopsidae (Heinberg 1976). The first paper contained information on biometric parameters, collecting procedures, localities and lithostratigraphic position of the hardground which has yielded the material.

\section{Systematic descriptions}

Family: Limposidae Dall, 1895

Genus: Limopsis Sassi, 1827

Type species: Arca auria Brocchi, 1814

\section{Limopsis maggae n. sp.}

Fig. 1

Holotype: MGUH 14400). Height $5.4 \mathrm{~mm}$, length ca $6.5 \mathrm{~mm}$

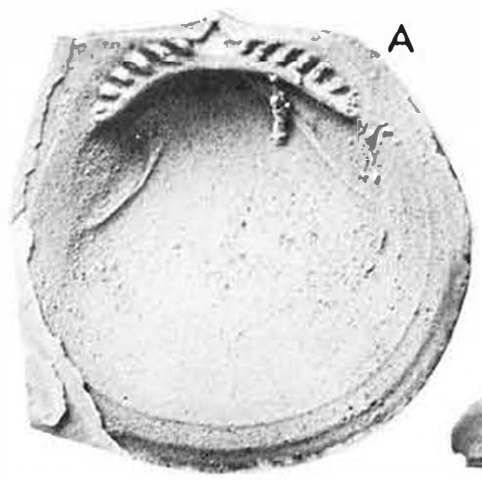

B2
Type locality: Stevns Klint, north of Kulsti.

Type stratum: The top hardground in the Upper Maarstrichtian white chalk.

Diagnosis: An equilateral, smooth shelled Limopsis, flat lenticular in shape, subcircular in outline; umbo small; shell margins moulding each other, the right margin having a commarginal ridge which fits into the commarginal furrow of the left margin; equal sized adductor scars with myophoric flanges; area circumscribed by pallial line bearing radiating striae.

Description: The shell is flat lenticular having a subcircular outline. It is nearly equilateral, the anterodorsal shell margin being straighter than the postero-dorsal one. The orthogyrate umbo is

Fig. I. Limopsis maggae n.sp. Al: Inside of a right valve, latex cast, holotype. MGUH 14400. x8. B1. B2: Outer surface of a left valve seen in side and amerior views, MGUH 14401. $x 8$. 
very small. The umbonal part of the shell is only slightly elevated, causing the dorsal flanks to be only a little steeper than the rest of the shell. The hinge line is straight and the rest of the shell margin forms a gentle curve which meets the hinge line at obtuse angles. The cardinal area is a flat symmetrical triangle with faint striae which are parallel to the hinge line. There is a triangular resilifer below umbo. The resilifer is divided into a median and two lateral sections, reflecting the alivincular type of ligament. The dentition is divided into two subsymmetrical series by an edentulous gap. The anterior series consists of up to seven, the posterior of up to eight teeth. All the hinge teeth radiate with respect to an area ventral of umbo. The shell surface is smooth, with regularly spaced growth lines. The smooth margins of the two valves are moulds of each other, the right valve having a convex, the left a concave profile. The inner surface of the shell is smooth with radiating striae characterising the area circumscribed by the pallial line. The two adductor scars are often clearly marked. They are of almost equal size and bordered by distinct myophoric flanges, the posterior of which runs into the umbonal cavity.

Maximum dimensions: Height 7.7. $\mathrm{mm}$, length $8.5 \mathrm{~mm}$, width $3.4 \mathrm{~mm}$.
Remarks: The peculiar shell margin is distinctive for the species.

Material: 38 specimens from Stevns Klint, including five from north of Kulsti, seven from north of Eskesti chalk pit, eight from north of Holtug chalk pit, eleven from Rødvig and seven from other parts of the cliff.

Family Arcidae Lamarck, 1809

Subfamily Arcinae Lamarck, 1809

Genus Arca Linné, 1758

Type species: Arca noae Schmidt, 1818

\section{Arca (Arca) ernae n.sp.}

Fig. 2

Holotype: MGUH 14402. Height $4.6 \mathrm{~mm}$, length $9.1 \mathrm{~mm}$, width $6.8 \mathrm{~mm}$.

Type locality: Stevns Klint, north of Eskesti chalk pit.

Type stratum: The top hardground in the Upper Maastrichtian white chalk.

Diagnosis: A relatively small, broad Arca (Arca) having a high, flat cardinal area; outline rhomboidal; distinct carina bordering plane, heavily ribbed corselet; anterior and posterior shell margins bearing distinct crenulae.
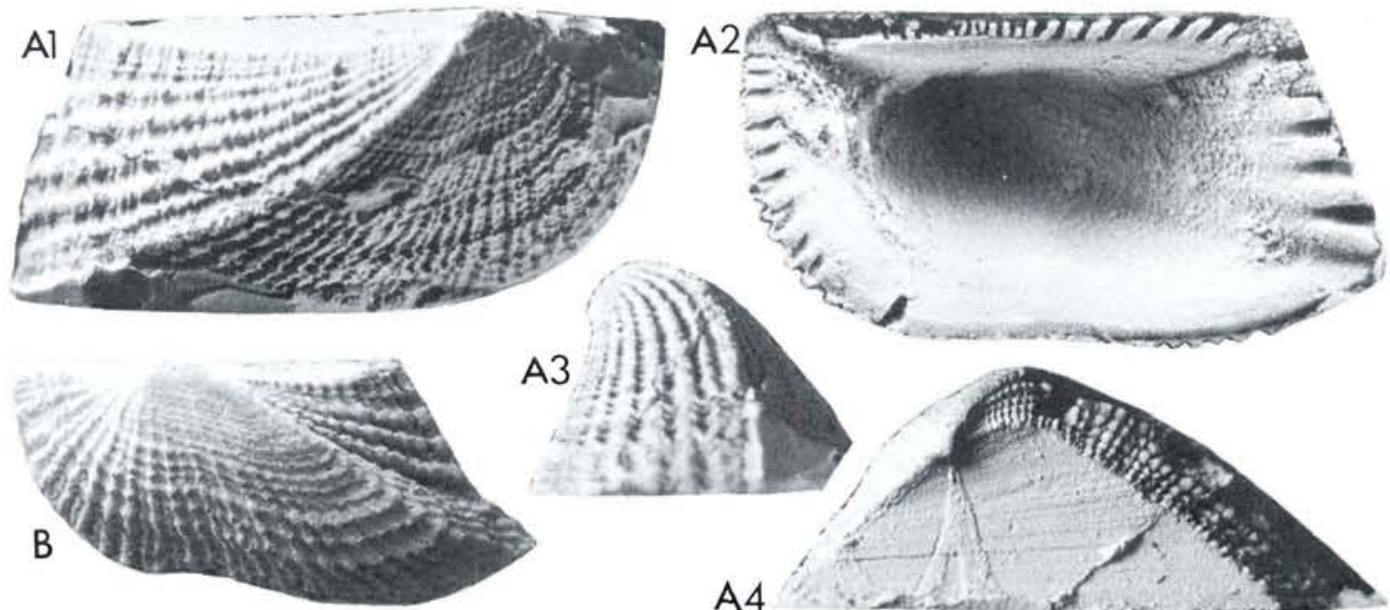

Fig. 2. Arca (Arca) ernae n.sp. A1, A2, A3, A4: Right valve seen in lateral view, from the inside, in posterior and dorsal views, larex cast, holotype, MGUH 14402. x7.5. B: Outer surface of a left valve, small individual, latex cast, MGUH 14403. $x 14$. 
Descriptions: The shell is rhomboidal in outline. It is equivalve, prosocline, the praeumbonal part of the shell constituting ca $32 \%$ of the total shell length. It is heavily in flated, the width of a single valve being ca 0.7 times the height. The hinge line is long and straight, the anterior and posterior shell margins are subparallel trending in an antero-dorsal/postero-ventral direction. The anterior margin is gently curved, continuing with no major change in curvature into the long sinus, which occupies a large part of the ventral margin. The relatively straight posterior margin forms a distinct angle with the ventral. In smaller individuals this angle is acute owing to a characteristic posterior projection of the postero-ventral shell corner. In larger specimens this projection disappears and the angle becomes obtuse. The umbo is small, hardly projecting above the cardinal area. The cardinal area is a flat triangle of considerable height (the height being ca $40 \%$ of the base). The cardinal area is striated with straight growth lines converging anteriorly. Ligament grooves descend from the umbo and bend towards the anterior as the hinge is approached. The hinge consists of a continuous series of rather uniform small teeth which radiate with respect to a point ventral of the umbo. On the shell surface a distinct carina separates the plane corselet from the rest of the shell. The sculpture is dominated by round-crested, radiating ribs which are most pronounced on the corselet. At a distance of ca $5 \mathrm{~mm}$ from umbo, the ribs occur at a density of three per $\mathrm{mm}$ on the flank, two per mm on the corselet. Growth lines crossing the radiating ribs are developed to a varying degree. Distinct growth lines form scales on the ribs of the corselet, knobs on rest of the shell. The inner surface of the shell is smooth, as is the ventral margin. The posterior and the anterior margins are dominated by large crenulae corresponding to the radiating ribs.

Maximum dimensions: Height ca $5 \mathrm{~mm}$, length $10.5 \mathrm{~mm}$, width $7.8 \mathrm{~mm}$.

Material: 20 specimens from Stevns Klint, including eight from north of Holtug chalk pit, seven from north of Eskesti chalk pit, one from Kulsti, two from Rødvig, and two from other parts of the cliff. The Lower Maastrichtian chalk of Møns Klint has yielded three specimens.

Genus Barbatia Gray, 1842

Type species: Arca barbata Linné, 1758

\section{Barbatia (Barbatia) forchammeri (Lundgren,} 1888)

Fig. 3

1867, Arca striata Lundgren, p. 27. Pl. 1, Fig. 8 1888, Arca forchammeri nov.nom. Lundgren, p. 229

1899, Barbatia tenuidentata Henning, p. 16, PI. 1, Fig. 9-11

1902, Barbatia tenuidentata Henning, Ravn, p. 54, Pl. 3 Fig. 9

1933, Barbatia faxensis Ravn, p. 13, PI. 1, Fig. $2 \mathrm{a}-\mathrm{b}$

Due to taxonomic confusion of the Danian/Maastrichtian barbatias, the species is redescribed on the basis of a specimen from the top

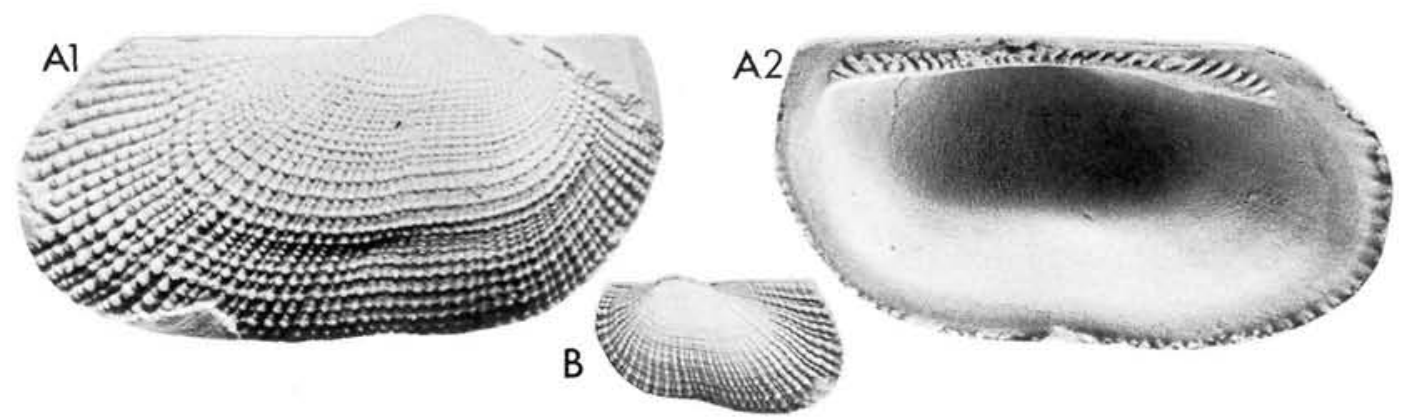

Fig. 3. Barbatia (B.) forchammeri (Lundgren). A1, A2: Outer and inner surfaces of a right valve, latex cast of MGUH 14404. x4.5. B: Outer surface of a left valve, latex cast, MGUH 14405. $x 4.5$. 
hardground in the Upper Maastrichtian white chalk at Stevns Klint. Material from the Danian deposits at Fakse and Annetorp has been examined in the absence of the original type material, which is lost.

Diagnosis: An elongate, ovate Barbatia, prosogyrate, having subparallel dorsal and ventral margins; dominant radiating and subdominant commarginal ribbing, crosspoints of ribs developed as tubercules or scales; posterior margin commonly undulating.

Description (based on MGUH 14404): The shell is equivalve, inequilateral with a smooth rounded ovate outline. The hinge line is straight, rest of the shell margin forming a gentle curve with the maximum curvature occurring posteriorly. The antero-dorsal shell angle is about $100^{\circ}$, the postero-dorsal about $135^{\circ}$. The prosogyrate umbo is prosocline, situated about $30 \%$ of the total length behind the anteriormost point of the shell. The shell is moderately inflated. There is indication of a sulcus connecting the umbo with the ventral margin. No carina is present. The cardinal area is a flat oblique triangle. The dentition is a continuous series of up to 34 rather uniform teeth that radiate with respect to a point ventral of umbo. The shell surface is dominated by round-crested radiating ribs, separated by U-shaped furrows of similar width. The radiating ribs are crossed by less pronounced commarginal riblets with sharp crests. At the crosspoints tubercules or scales are formed. At a distance of $4 \mathrm{~mm}$ from the umbo, the radiating ribs occur a number of 5-6 per $\mathrm{mm}$, the commarginal at $2-3$. New ribs are added between the primary ones. The inner surface of the shell as well as the shell margin is smooth, except for occasional undulations posteriorly. Judged from the recent species $B$. fusca (Bruguière, 1789), such undulations of the margin are of a highly variable character. It may be linked to the periodicity in growth. There is a rounded anterior adductor scar, and dorsal of this a small pedal muscle scar.

Dimensions of specimen described: Height 6.6 $\mathrm{mm}$, length $14.1 \mathrm{~mm}$, width $5.6 \mathrm{~mm}$.

Maximum dimensions: Height ca. $10.5 \mathrm{~mm}$, length ca $21 \mathrm{~mm}$, width ca $8 \mathrm{~mm}$.
Discussion: There is close morphological resemblance among the Maastrichtian Barbatia described above, and the two Danian species $B$. faxensis Ravn, 1933 and $B$. forchammeri (Lundgren, 1888). While the Maastrichtian specimen here described has a small antero-dorsal angle (ca $100^{\circ}$ ), there is a tendency for large individuals from the Danian to have a larger antero-dorsal angle (ca $130^{\circ}$ ). However, the $100^{\circ}$ angle is well within the range of variation of the Danian material.

It thus seems that, among large specimens of this species group, Danian individuals tend to have a more projecting anterior part than Maastrichtian ones, smaller individuals being almost identical. On the basis of the variation range in the present material this difference is not regarded as sufficient for the creation of a separate Maastrichtian species, and, further, Ravn's (1933) Barbatia faxensis is regarded as a junior synonym. Thus all specimens here dealt with are regarded as the same species. In any case, it seems obvious that we are dealing with one evolutionary lineage.

Material: Ten specimens from Stevns Klint, comprising four from north of Holtug chalk pit, one from Kulsti, one from Rødvig and four from other parts of the cliff.

\section{Barbatia (Acar) hennigi n.sp.}

Fig. 4

Holotype: MGUH 14406. Height 5.5. mm, length $13.3 \mathrm{~mm}$, width ca $6 \mathrm{~mm}$.

Type locality: Stevns Klint.

Type stratum: The top hardground in the Upper Maastrichtian white chalk.

1899, Barbatia forchammeri (Lundgren), Hennig, p. 15, Pl. 1, (non Lundgren 1888)

1902, Arca (Barbatia) forchammeri Lundgren, Ravn, p. 53. Pl. 3, Fig. 10

Diagnosis: An elongate, inequivalve thombiodal Acar having subparallel downwards and backwards tapering anterior and.posterior margins; anterior margin curving gently into the sinuous ventral margin; the posterior margin straight, meeting the ventral at an acute angle. Adductor scars distinct, having myophoric ridges; orna- 


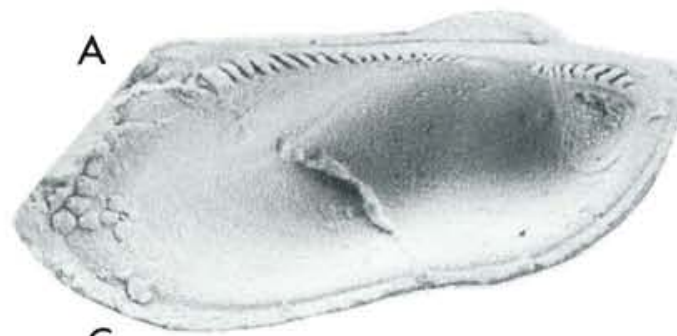

C

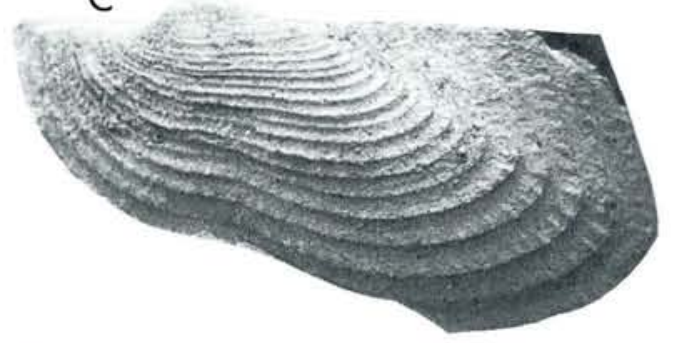

Fig. 4. Barbatia (Acar) hennigi n.sp. A: Left valve, inner surface. Specimen from the Upper Maastrichtian of Stevns Klint. Latex cast, MGUH 14406. x5.3. B: Left valve, inner surface. Specimen from the Lower Maastrichtian of Møns Klint, latex

mentation of commarginal broad ribs has bars arranged in a radiating pattern.

Description: The shell is inequivalve, elongate rhomboidal and rather flat. It is inequilateral, prosocline, the praeumbonal part of the shell constituting between $23 \%$ and $28 \%$ of the total length. The anterior and posterior margins are subparallel, inclined posteriorly towards the ventral margin. The anterior margin curves gently into the ventral margin, the latter being slightly sinuous. The posterior margin is straight and meets the ventral margin at an acute angle. The umbo is prosogyrate. The cardinal area is a flat oblique triangle, the height of which constitutes ca $6 \%$ of the base. The hinge is separated into two series by an edentulous gap. The anterior series consists of up to 10 platy teeth, which radiate with respect to a point below the umbo. The posterior series consists of up to 19 platy teeth radiating with respect to a point antero-ventral of umbo. In large specimens the anterior third of this posterior series is reversed so that the teeth radiate with respect to a point postero-ventrally of umbo. The shell surface is dominated by broad and flat commarginal ribs, crossed by discontinuous radiating bars. Anteriorly the radiating element tends to cease. There is a distinct carina connecting the umbo with the postero-ventral
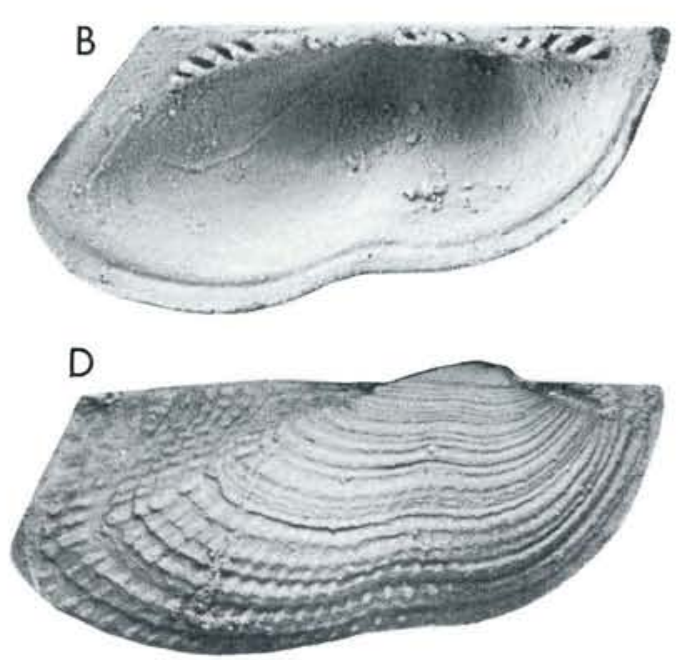

cast, MGUH 14407. x9.4. C: Left valve, outer surface. Specimen from the Danian of Fakse, latex cast, MGUH 14408. x9.3. D: Right valve, outer surface. Specimen from the Lower Maastrichtian of Møns Klint, latex cast, MGUH 14409, x10.

shell corner. The carina separates the plane corselet and the faint sulcus running ventrally from the umbo, corresponding to the ventral sinus. On the corselet the broad ribs may develop into raised lamellae. At a distance of $4 \mathrm{~mm}$ from the umbo, the density of commarginal ribs is ca 2.5 per $\mathrm{mm}$, while the radiating elements occur at a density of ca 4 per $\mathrm{mm}$. The inner surface of the shell is smooth with well marked somewhat raised adductor scars. The anterior adductor scar is subcircular, the larger posterior scar is ovate, trunctated at the umbonal end. From the inner margins of the scars a distinct riblet runs towards the umbo. The shell margin is smooth. The margin of the left valve is characterised by a flat shelf which runs parallel to the edge for some distance. Dorsally, the shelf merges into the hinge plate. The shelf is probably the plane of contact between the two valves, thus indicating that the right valve is the smaller, a common feature in inequivalve barbatias.

Maximum dimensions: Those of the holotype.

Discussion: The species was described, and incorrectly referred to Barbatia forchammeri Lundgren by Hennig (1899), a name adopted by Ravn (1902). However, the figures of both Lundgren (1867) and Hennig (1899) make it 
clear that this is a new species, distinct from Barbatia forchammeri (Lundgren).

In the absence of the original types, additional material from the Danian of Annetorp and Fakse has been examined. The Danian material is essentially similar to the Maastrichtian species described above. It may differ in being more variable in shape and having slightly coarser sculpture. The sculpture of the Danian specimens tends to be lamellar in a manner reminiscent of Acar cf. lamellosa (Deshayes, 1858) from the Danian of Ciply (Vincent 1930, Glibert and Van de Poel 1973). The taxonomic relation between Acar forchammeri and Acar lamellosa deserves further investigation.

Reinhardt (1935) mentions Acar forchammeri as the oldest member of the subgenus.

Material: 16 specimens from Stevns Klint, comprising five from north of Holtug chalk pit, two from north of Esketi chalk pit, two from Rødvig, four from Kulsti and three from other parts of the cliff. The lower Maastrichtian chalk of Møns Klint has yielded two specimens.

\section{Barbatia (Obliquarca?) lindae n.sp.}

\section{Fig. 5}

Holotype MGUH 14410. Height $5.2 \mathrm{~mm}$, length $8.3 \mathrm{~mm}$, width $4.6 \mathrm{~mm}$

Type locality: Stevns Klint at Rødvig

Type stratum: The top hardground in the Upper Maastrichtian white chalk.

Diagnosis: A strongly inequilateral, prosogyrate Barbatia, having reduced anterior; maximum

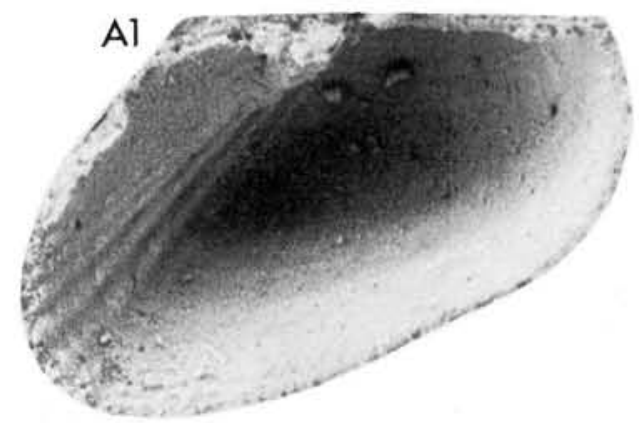

Fig. 5. Barbatia (Obliquarca?) lindae n.sp, A1, A2: Inner and outer surfaces of a left valve, latex cast, holotype, MGUH 14410. $x 7.7$. height posterior to the long and straight hinge line; ventral margin and hinge line converge anteriorly, the former carrying a faint sinus; a distinct carina bordering corselet with prominent sharp crested, radiating ribs; anterior slope having radiating, somewhat dorsally curving riblets; area of the median sulcus showing very faint radiating striae; inner surface smooth; anterior adductor scar bordered by small myophoric ridge.

Description: The shell is modioliform, strongly inequilateral, the preumbonal part constituting ca $18 \%$ of the total length. It has a rounded subtrapezoidal outline with a long straight dorsal margin and a slightly sinuous ventral one. These two margins converge anteriorly, together describing an angle of ca $24^{\circ}$. The anterior and posterior margins curve gently into the ventral margin. The antero-dorsal angle is ca $107^{\circ}$, the postero-dorsal ca $125^{\circ}$. The postero-ventral shell corner is heavily enlarged, projecting postero-ventrally, causing the maximum height of the shell to lie posterior to the hinge. The umbo is prosogyrate, well developed, somewhat projecting above the hinge line. The cardinal area is not preserved, but judging from the inner surface of the shell it is narrow, Barbatia-like. The shell surface is ornamented with radiating ribs and striae as well as commarginal growth lines. The corselet and the distinct carina bordering it, is dominated by sharp-crested ribs that are separated by broad $\mathrm{U}$-shaped furrows. The ribs occur at a density of three per $\mathrm{mm}, 4 \mathrm{~mm}$ from umbo. On the anterior slope sharp-crested riblets are separated by broad flat interrib areas. At a distance of $3 \mathrm{~mm}$ from

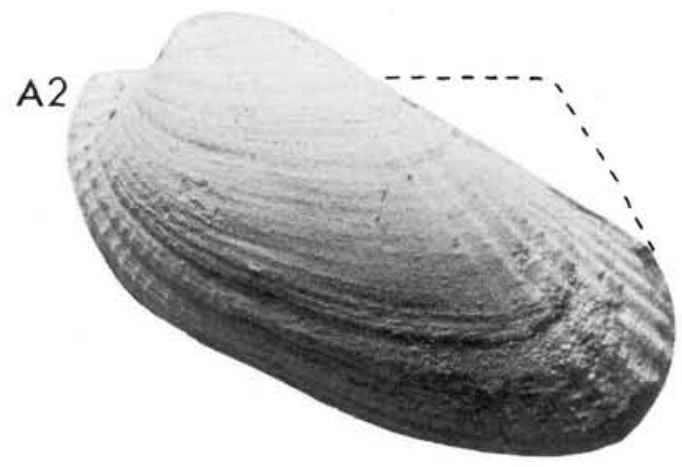


umbo, the riblets occur at a density of four per $\mathrm{mm}$. The central, somewhat sulcate part of the shell has a smooth appearance because of the small size of the radiating striae occurring there. The striae occur at a density of six per $\mathrm{mm}, 3 \mathrm{~mm}$ from umbo. The radial ornamentation is crossed by rather indistinct growth lines that may develop into varices. The hinge is not preserved except for the two anteriormost teeth, which have a knob-like appearance. The inner surface of the shell is smooth except for a radiate ribbing posteriorly, corresponding to the heavy ribs on the carina. The anterior adductor scar is bordered by a small myophoric ridge. The area of the anterior scar is not complete, but it seems that no such ridge is present here.

Maximum dimensions: those of the holotype. Material: One left valve from Rødvig, Stevns Klint.

Subfamily Anadrinae Reinhart, 1935

Genus Bathyarca Kobelt, 1891

Type species Arca pectunculoides Scacchi, 1833

\section{Bathyarca perla n.sp.}

Fig. 6

Holotype: MGUH 14412. Height $3.5 \mathrm{~mm}$, length ca $4.7 \mathrm{~mm}$, width $3.4 \mathrm{~mm}$

Type locality: Stevns Klint north of Holtug chalk pit
Type stratum: The top hardground in the Upper Maastrichtian white chalk.

Diagnosis: A Bathyarca having distinct radial ribbing, shell margin crenulate except for the most dorsal parts, each crenula corresponding to a surface rib.

Description: The shell is equivalve, inequilateral and moderately inflated, being rounded subtrapezoidal in outline. The well developed umbo is prosogyrate, projecting dorsally above the cardinal area. The umbonal part of the shell is well developed resulting in a rather steep slope of the dorsal flanks. As the shell margin is approached, these flanks flatten. A poorly defined carina connects the umbo with the postero-ventral shell corner. The hinge line is straight, the rest of the shell margin forms a gentle curve with a maximum in curvature postero-ventrally. The shell margin meets the hinge line at a more obtuse angle posteriorly than anteriorly. The cardinal area is a flat triangle where the anterior side is straight while the posterior is concave (in dorsal view). In young specimens the dentition is continuous. In adults it is separated into an anterior and a posterior series by an edentulous gap. The anterior series consists of at least seven parallel teeth trending in a postero-ventral direction (hinge of a larger specimen not preserved). The po-

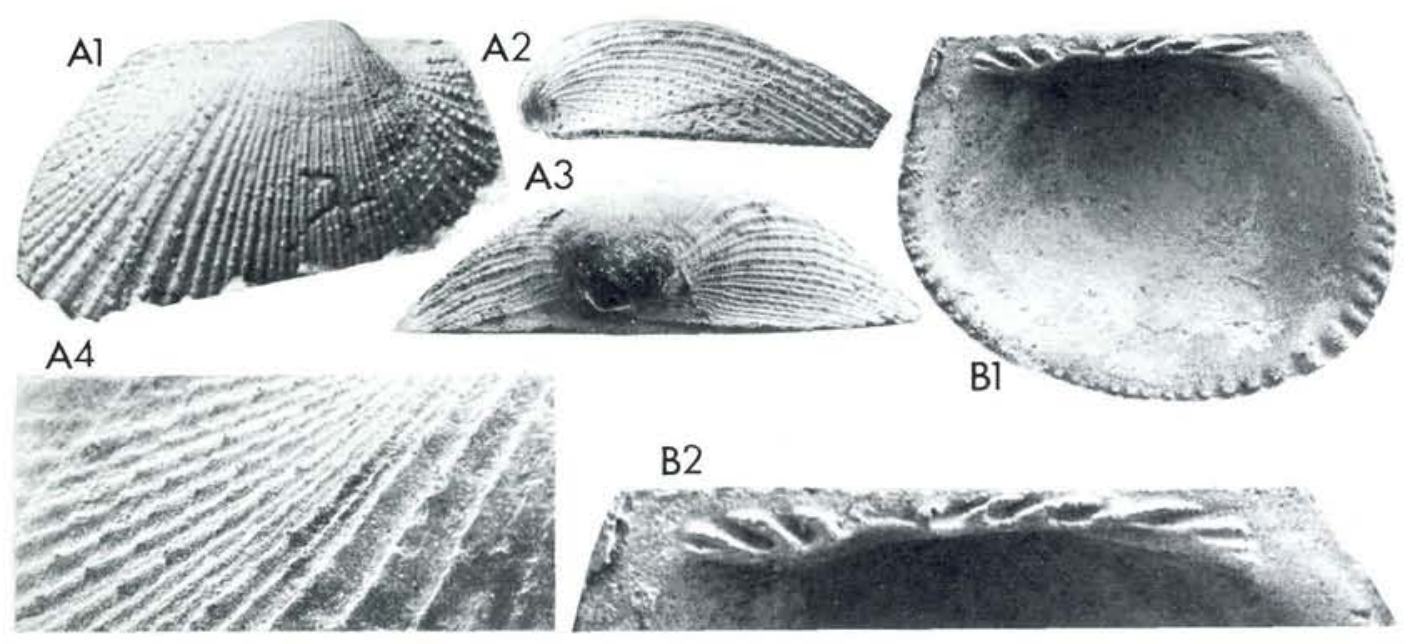

Fig. 6. Bathyarca perla n.sp. A1, A2, A3: Outer surface of a right valve, latex cast, MGUH 14411. x8.6. A4: detail of A1, 40. B1: Inner surface of a right valve, latex cast, holotype, MGUH 14412. x11.6. B2: Detail of B1, x22. 

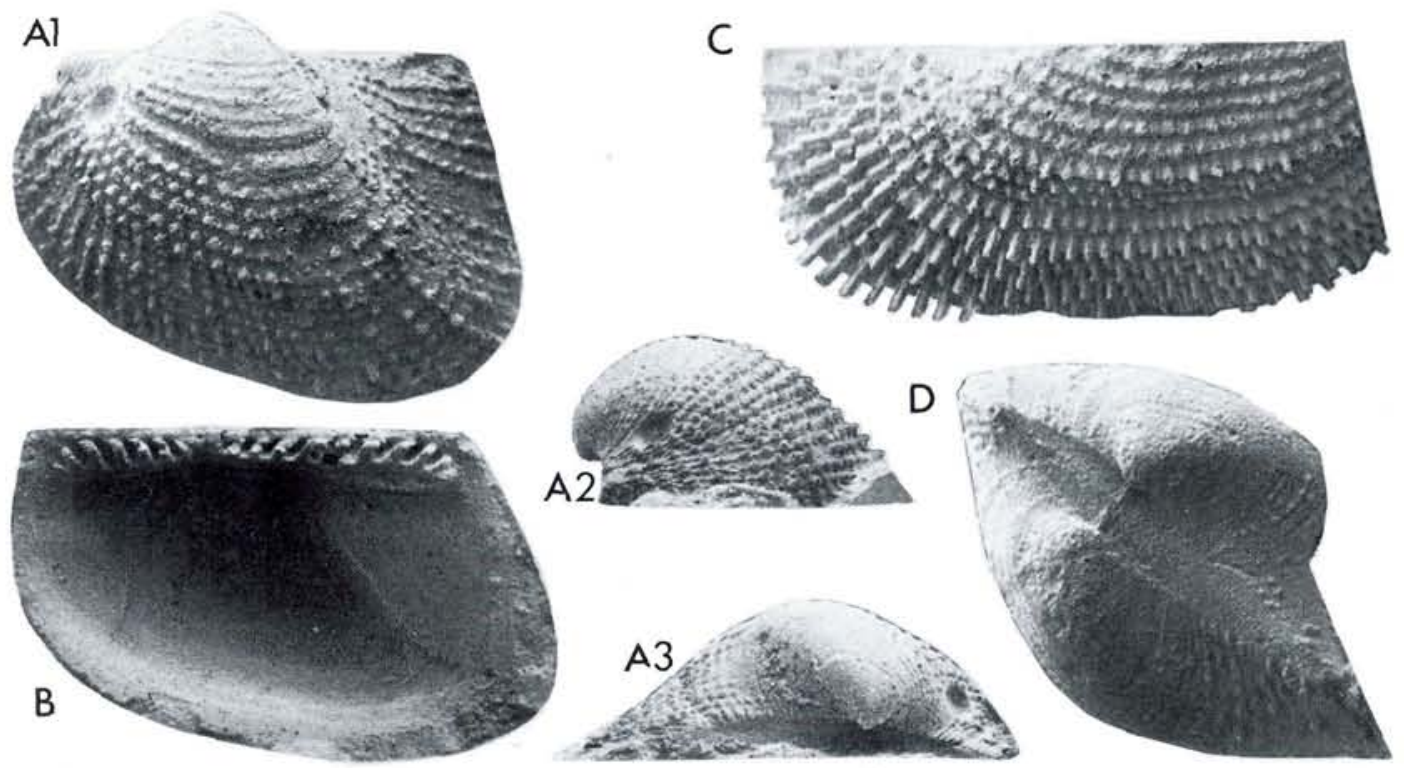

Fig. 7. Arcopsis (Arcopsis) christinae n.sp. A1, A2, A3: Outer surface of a left valve, latex cast, holotype, MGUH 14413. xI6. B1: Inner surface of a right valve, latex cast, MGUH 14414. x14.
C: Detail of ornamentation, latex cast, MGUH 14415, x22. D: Dorsal view of a bivalved specimen showing the ligament pit. Latex cast, MGUH 14416. x33.

Genus Arcopsis Koenen, 1885

Type species Arca limopsis Koenen, 1885

Arcopsis (Arcopsis) christinae n.sp.

Fig. 7

Holotype: MGUH 14413. Height $2.3 \mathrm{~mm}$, length $3.2 \mathrm{~mm}$, width ca $2 \mathrm{~mm}$.

Type locality: Stevns Klint, north of Eskesti chalk pit.

Type stratum: The top hardground in the Upper Maastrichtian white chalk.

Diagnosis: An Arcopsis having heavy ornament consisting of commarginal lamellae with spines or tubercules arranged in a radiating pattern. Inner margins of adductor scars bordered by a raised myophoric flange.

Description: The shell is equivalve, inequilateral (prosocline) with an ovate outline, the anterior part being somewhat reduced. It is heavily inflated, reaching a considerable width relative to height. In a large specimen the width of the shell is 1.6 times the height. The well developed umbo is proso- to orthogyrate, projecting dorsally above the cardinal area. Due to the overall inflation of the shell the dorsal flanks are very steep. The 
hinge line is straight, while the rest of the margin forms a gentle curve having a maximum of curvature postero-ventrally. The cardinal area is a flat, oblique triangle with a narrow resilifer below umbo. There is a well developed carina connecting the umbo with the postero-ventral shell corner. The corselet is flat to slightly concave. The hinge consists of up to 17 platy teeth arranged in two series separated by an edentulous gap. The seven anterior teeth radiate with respect to a point antero-ventral of umbo, the posterior series with respect to a point postero-ventral of umbo. The shell surface is generally heavily sculptured though considerable variation occurs in this character. The sculpture consists of two elements, a radiating and a commarginal one, both of which can develop to a varying degree, causing the great array of sculptures characteristic for the species. Two characteristic types of sculpture are described:

1) The sculpture is dominated by commarginal raised lamellae carrying relatively long spines in a radiating pattern. The most prominent spines are found on the carina. Measured $2 \mathrm{~mm}$ from the umbo, the density of spines parallel to the margin are 11 per $\mathrm{mm}$, while lamellae occur at a rate of seven pr mm.

2) The sculpture consists of commarginal ribs crossed by radiating ribs, forming smaller or larger tubercules at the crossing points. The dominating element may be either the commarginal or the radiating. In the latter case the tubercules may develop into scaly spines on the carina. Completly smooth shells are often found, but the lack of ornament probably has a diagenetic origin owing to calcitic cement filling in irregularities on the shell imprint subsequent to aragonite dissolution. A few specimens have smooth patches on the otherwise sculptured shell surface. (Exactly the same phenomena are reported by Sheldon (1916), and by Hanna (1927 p. 272), working with the preserved shells of tertiary Arcopsis. These authors relate the smooth patches on the shell to breaking off of the shell sculpture. This is another possible explanation for the present material).

The shell margin is smooth, as is the inner surface of the shell. The inner margins of the equal sized adductor scars are bordered by distinct myophoric flanges (which is also the case in von Koenen's type specimen).
Maximum dimensions: Height $3.5 \mathrm{~mm}$, length 5.8 $\mathrm{mm}$, width $5.5 \mathrm{~mm}$.

Affinities: The species is close to the Paleocene species Arca limopsis Koenen (genotype for Arcopsis) and to the Danian Arcopsis bruenichi Ravn 1933. It differs from these two species in the shell sculpture, though the less ornamented examples of $A$. christinae show some resemblance. Whether Arcopsis limopsis Koenen and Arcopsis bruenichi Ravn are separate species or not, deserves investigation.

Material: 70 specimens from Stevns Klint, including 14 from north of Kulsti, 14 from north of Eskesti chalk pit, 18 from north of Holtug chalk pit, 14 from Rødvig and 10 from other parts of the cliff.

Family: Parallelodontidae Dall, 1898

Subfamily: Grammatodontinae Branson, 1942

Genus: Catella Healey, 1908

Type species: Grammatodon (Cosmetodon) laticlava, 1908

\section{Catella katinkae n.sp.}

Fig. 8

Holotype: MGUH 14417. Height $2.2 \mathrm{~mm}$, length $3 \mathrm{~mm}$, width $1.6 \mathrm{~mm}$.

Type locality: Stevns Klint, north of Kulsti.

Type stratum: The top hardground in the Upper Maastrichtian white chalk.

Diagnosis: A Catella having distinct, reticulate ornamentation; prominent median sulcus; outline subtrapezoidal sulcate, reduced anteriorly; supposed pallial line crenulated.

Description: The shell is equivalve, inflated, having a subtrapezoidal outline. The posterior margin is straight, the ventral and anterior margins form a gentle curve, probably interrupted by a ventral sinus. The shell is heavily inequilateral, being enlarged posteriorly. The distinct umbo is prosocline, prosogyrate, projecting dorsally above the cardinal area. The umbonal part of the shell is inflated, causing steep dorsal flanks. The shell is characterised by a distinct median sulcus connecting the umbo with the ventral margin. The dentition is separated into an anterior and a posterior series by an edentulous gap. The ante- 
rior series consists of three platy and parallel teeth that trend in an antero-dorsal/postero-ventral direction. The posterior series consists of four teeth oriented subparallel to the hinge line. The anteriormost and the most dorsal one is small. The remaining three are heavily elongated, the middle one being the longest. The anterior ends of these teeth intersect the ventral margin of the hinge plate. The shell surface is covered by a reticulate ornamentation caused by radiating ribs and very regular growth lines. At a distance of 2 $\mathrm{mm}$ from umbo, the commarginal ribs occur at a number of 5-6 per $\mathrm{mm}$, the radiate with 9 per $\mathrm{mm}$. The shell margin is smooth. The inner surface of the shell is characterised by a commarginal shelf-like flattening which dorsally merges into the hinge plate. This shelf is supposed to represent the pallial line. Posteriorly the shelf is smooth; the rest of it is crenulated in a characteristic manner. The crenulae continue as striations covering the inner surface towards the umbo, except for the two adductor scars. The posterior adductor scar is the larger.

Maximum dimensions: Height ca $2.8 \mathrm{~mm}$, length $4.5 \mathrm{~mm}$.

Affinities and systematic discussion: The species shows affinities to Grammatodon, but the lack of a carina, and the presence of the distinct sulcus, places it in the genus Catella Healy, 1908. The internal morphology of $C$. katinkae is almost identical to that of $C$. voigti (Roed) from the Paleocene of Copenhagen (Ravn, 1939, Pl. 1 fig. 1). However, C. katinkae is well distinguished by the characteristic reticulate ornamentation of the shell surface, a feature which also separates it from the Jurassic species from Sweden, Catella sinuatus Troedsson. The latter has coarse, elevated growth lines (Troedsson 1951). Reuss (1846) described and figured a species, Arca bifida Reuss, which closely resembles a Catella, and which also has a reticulate shell surface. The description, which does not match too well with the figure, does not mention the hinge. However, Reuss compared his species with Arca quadrilaterata Lamk. as is figured in Goldfuss 1937 (pl. 122, fig. 5). This species has a hinge characteristic of an Arca, and therefore the generic status of Arca bifida Reuss seems doubtful. The Maastrichtian Fox Hills Formation of the Western Interior contains a similar species, $\mathrm{Pa}$ rallelodon (Cosmetodon) sulcatinus (Evans \& Shumard), (Speden 1970), which however differs from Catella katinkae mainly in the outer sculpture.

Material: Six specimens, all from the locality at Kulsti, Stevns Klint. The Lower Maastrichtian chalk of Møns Klint has yielded two specimens.

Genus: Pseudogrammatodon, Arkell 1930

Type species: Arca adversidentata Deshayes, 1958

\section{Pseudogrammatodon lornae n.sp.}

Fig. 9

Holotype: MGUH 14418. Height $5 \mathrm{~mm}$, length $7.6 \mathrm{~mm}$, width $3.8 \mathrm{~mm}$.

Type locality: Stevns Klint, north of Kulsti. Type stratum: The top hardground in the Upper Maastrichtian white chalk.

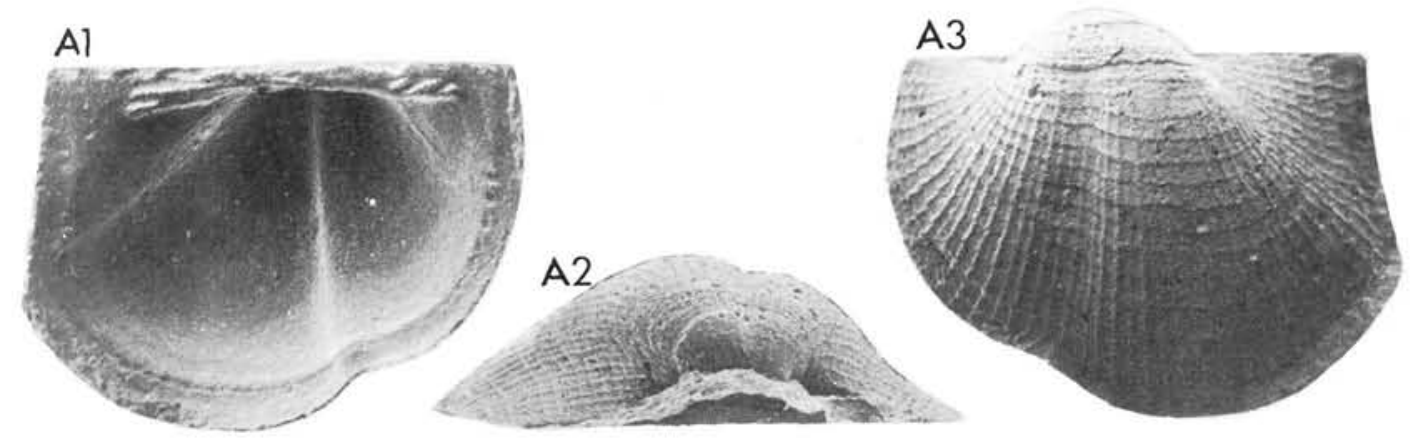

Fig. 8. Catella katinkae n.sp. A1, A2, A3: Left valve seen from the inside and in dorsal and lateral views, latex cast, holotype, MGUH 14417. xI6. 


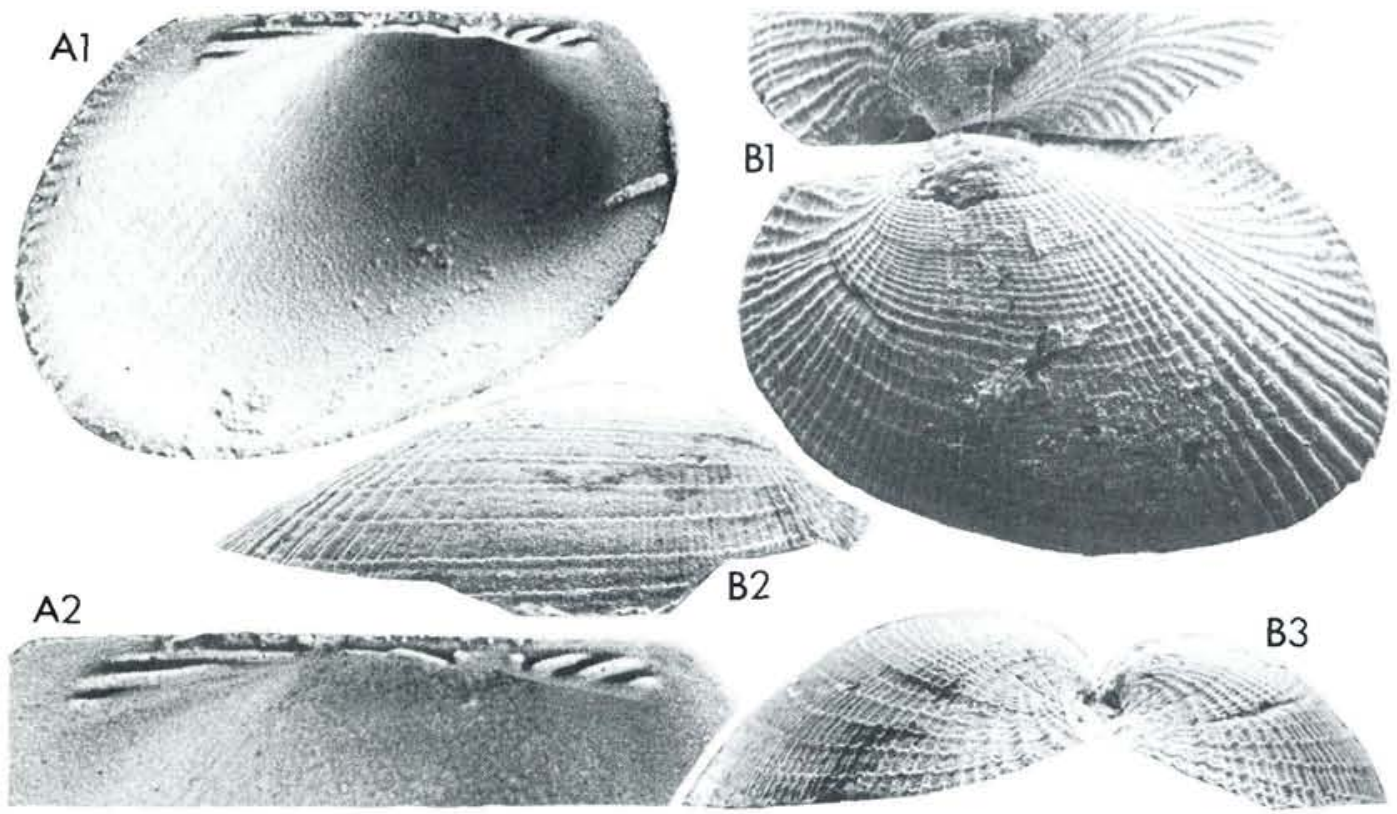

Fig. 9. Pseudogrammatodon lornae n.sp. Al: Inner surface of a left valve, latex cast, holotype, MGUH 14418. x9. A2: Detail of
A1 x14. B1, B2, B3: Outer surface of the shell, seen in lateral, ventral and anterior views, MGUH 14419. x13.
Diagnosis: An ovate grammatodontid, inequilateral, anterior somewhat reduced; ribs on dorsal flanks curve dorsally; hinge having prominent teeth, anterior series four smaller oblique teeth, posterior series long teeth parallel to hinge line, anterior ends of which intersect ventral margin of hinge plate; posterior shell margin undulated.

Description: The shell is equivalve, relatively flat, having an oblique ovate outline. The hinge line is straight, the rest of the margin forms a gentle curve which meets the hinge line at obtuse angles anteriorly and posteriorly. The maximum curvature is around the enlarged postero-ventral shell corner. A very faint ventral sinus may be present. Otherwise the ventral margin is straight or convex. The shell is inequilateral, having a distinctly enlarged posterior part, the umbo being in a prosocline position. The umbo is distinct but small, prosogyrate and hardly projects dorsally above the cardinal area. The shell is generally flat, the umbonal part only somewhat elevated. The dorsal flanks flatten out characteristically as the shell margin is approached. The cardinal area has the shape of an oblique triangle. No trace of ligament is observed. The dentition consists of two series, separated by a narrow edentulous gap.
The posterior series consist of up to four teeth, of which the anterior-most is a small knob. The remaining three are elongated and oriented parallel to the hinge line. From the large dorsal one, the teeth become smaller ventrally. The anterior ends of the teeth intersect the ventral margin of the hinge plate. The anterior series consist of up to four teeth of which the median two are elongated. They form an $20^{\circ}$ angle with the hinge line. The shell surface is dominated by radiating ribs, which are most prominent anteriorly and posteriorly. As the dorsal flanks are approached, the ribs tend to be increasingly curved. On the flanks this peculiar curve is associated with a marked fusing of the ribs. At a distance of $3 \mathrm{~mm}$ from the umbo the ribs occur at a number of ten per $\mathrm{mm}$, decreasing to three per mm postero-ventrally, where the ribs are broadest. The radiating sculpture is associated with concentric growth lines forming rather distinct varices at regular intervals. The inner shell surface is smooth except for some faint posterior undulations corresponding to the prominent ribs connecting the umbo with the postero-ventral shell corner. This also causes the posterior shell margin to be wavy, whereas the rest of the margin is smooth. No adductor scars were observed. 
Maximum dimensions: Those of the holotype.

Discussion: The species is clearly a Pseudogrammatodon Arkell, 1930 despite the fact that several authors (Newell 1969, Reinhardt 1935, and to some degree Arkell 1929-37, p. xxi) regard this genus as a synonym of Porterius Clark 1925. However, the diagnosis of Clark (1925) states that Porterius has »three fairly large trenasverse teeth, followed by 15 or 16 much smaller transverse teeth ... The long posterior teeth at their anterior ends are above the anterior taxidont teeth ...«. This type of dentition clearly distinguishes Porterius Clark 1925 from Arca adversidentatus Deshayes, type species of Pseudogrammatodon Arkell, 1930. As stated by Glibert and Van de Poel 1965, the validity of Porterius itself needs justification since it seems to be very close to the genus Cucullaria Conrad, 1860 (Type: Arca heterodonta Deshayes, 1860).

Judging from the description by Lehner (1937), the Upper Turonian Grammatodon undulatus (Reuss) is to be considered an early representative of Pseudogrammatodon. P. lornae shows some resemblance to the Danian Pseudogrammatodon macrodon (Lundgren) (Ravn 1902, pl. 3, fig. 11). However, this species lacks the dorsally curving ribs and the anterior teeth are nearly parallel to the hinge line. Von Koenen (1893) figured a specimen of the Oligocene Arca decussata Nyst. (pl. 70, fig. 14 b) (regarded a Porterius by Reinhardt, 1935 p. 25). This species has dorsally curving ribs on the antero-dorsal flank, but not on the posterior. In addition, the posterior teeth are shorter than in P. lornae.

Material: 33 specimens from Stevns Klint, comprising 11 from north of Holtug chalk pit, seven from north of Eskesti chalk pit, eight from Rødvig, five from Kulsti and two from other parts of the cliff.

Acknowledgements. This study has been supported by grants from the Carlsberg Foundation. R. Bromley read the manuscript and improved the language. H. W. Rasmussen offered helpful suggestions. J. Aagaard prepared the photographs.

\section{Dansk sammendrag}

Denne beskrivelse af 9 (hvoraf 8 nye) arter af muslinger udgør fortsattelsen af et tidligere arbejde (Heinberg 1976). Muslingerne stammer fra hærdningshorisonten på Stevns Klint som dateres til $\emptyset$. Maastrichtian. Flere af slægterne er typisk tertiære og udgør således et moderne element $i$ en fauna som ellers tilhører kridttiden. En tidligere forkastet slagt, Pseudogrammatodon Arkell, 1930, genopstilles.

\section{References}

Arkell, W. J., 1929-37: A monograph of British Corallian Lamellibranchia. Palaeontograph. Soc. London. 392 pp.

Clark, B. L., 1925: Pelecypoda from the Marine Oligocene of Western North America. Univ. Calif. Publ. Geol. Sci. 15: 71-107.

Deshayes, G. P., 1860: Description des Animaux sans vertébres découverts dans le Bassin de Paris. I: 909 pp. Paris. J.-B. Baillière et Fils.

Glibert, M. \& Van de Poel, L., 1965: Les bivalvia fossiles du cénozoique étranger. Mém. Inst. Roy. Sci. Nat. Belg. 77 1-112.

Glibert, M. \& Van de Poel, L., 1973: Les Bivalvia du Danien et du Montieu de la Belgique. Mém. Inst. Roy. Sci. Nat. Belg. 175: 1-89.

Goldfuss, A., 1837: Petrefakta germania I: 141-224. Dũsseldorf. Arnz \& Co.

Hanna, M. A., 1927: An Eocene invertebrate fauna from the La Jolla Quadrangle, California. Univ. Calif. Publ. Geol. Sci. 16: 247-398.

Heinberg, C., 1976: Bivalves from the white chalk (Maastrichtian) of Denmark: Limposidae. Bull. geol. Soc. Denmark 25: $57-70$.

Hennig, A., 1899: Faunan i Skånes yngre Krita II. Lamellibranchiaterna. Bihang till $K$. Svenska Vet.-Akad. Handlingar. Bd 24, Nr. 7: 1-35.

Koenen, A. von, 1885: Über eine Paleocäne Fauna von Kopenhagen. Abh. d.K.Ges.d. Wiss. Gôttingen. Bd. 32, 128 pp.

Koenen, A. von, 1893: Das Norddeutsche Unter-Oligocan und seine Mollusken-Fauna: 5. Pelecypoda. Abh. geol. Specialkarte v. Preussen. Bd. 10: 1005-1244.

Lehner, L. 1937: Fauna und flora der Fränkischen Albüberdeckenden Kreide. I. Die Lamellibranchiaten. Palaeontographica, 85: 115-228.

Lundgren, B. 1867: Palaeontologiska Iakttagelser öfver Faxekalken på Limhamn. 1-31. Lund, Lunds Univ. Arsskrift.

Lundgren, B. 1888: Några anteckningar om Sveriges kritfauna. Öfvers. af $K$. Vetenskaps Akad. Förhandl.: 225-231.

Newell, N. D. 1969 in Moore (ed.) Treatise on Invertebrate Paleontology, N (1): 489 pp. Lawrence: Kansas Univ. Press.

Ravn, J. P. J. 1902: Molluskerne i Danmarks Kridtaflejringer I. Lamellibranchiater. Kgl. Danske Vidensk. Selsk. Skr. 6 nat. mat. afd. 11: 74-138.

Ravn, J. P. J, 1933: Études sur les Pélécypodes et Gastropodes daniens du Calcaire de Faxe. Kgl. Danske Vidensk. Selsk. Skr. nat. mat. afd. 9: 1-71.

Ravn, J. P. J. 1939: Études sur les Mollusques du Paléocéne de Copenhague. Kgl. Danske Vidensk. Selsk. Biol. Skr. 1: 1-106.

Reinhart, P. W. 1935: Classification of the pelecypod family Arcidae. Bull. Mus. roy. Hist. nat. de Belgique 11: 1-68.

Reuss, A. E. 1846: Die Versteinerungen der Böhmischen Kreideformation. 2: 1-140.

Sheldon, P. G. 1916: The Atlantic Slope Arcas. Palaontographica Americana 1: 1-101.

Speden, I. G. 1970: The Type Fox Hills Formation, Cretaceous (Maastrichtian), South Dakota Part 2. Peabody Museum Bulletin 33: 222 pp.

Troedsson, G. 1951: On the Höganās series of Sweden. Skr. Från Min. och Paleont. - Geologiska inst., Lund 7,258 pp.

Vincent, E. 1930: Mollosques des Couches a Cyrènes. Mem. Mus. roy. Hist. nat, de Belgique 43: 1-43. 